\title{
Monitoring the end of the in vitro phase of Anthurium andreanum Lindl. plantlets
}

\author{
Giulio Cesare Stancato ${ }^{1 *}$ and Maria Luiza Sant'Anna Tucci ${ }^{1}$ \\ ${ }^{1}$ Centro de Horticultura, Instituto Agronômico (IAC), Caixa Postal 28, 13012-970, Campinas, SP, Brasil. \\ * Corresponding author: stancato@iac.sp.gov.br \\ Received: 01 September 2009; Accepted: 14 May 2010
}

\begin{abstract}
Estimulation of autotrophy in in vitro plantlets could be achieved through changes in the culture medium, or by changing the traditional hermetic caps by one that could allow gas exchanges between the culture and the environment. Besides that, the use of lamps with distinct emission spectrum irradiaction has propitiated successful results. This work was carried out aiming to evaluate the either the combined or the single action of some factors that can induce autotrophy on in vitro A. andraeanum cv. Eidibel plantlets. 3 sucrose concentrations were used: 0,15 and $60 \mathrm{mM}$ and for each one, to kinds of flasks according to the cap ventilation: under $\left(0.038{\mathrm{~L} . \mathrm{h}^{-1}}^{-1}\right)$ and without ventilation. Flasks were kept under cold light fluorescent lamps or under gro-lux lamps. At the end of the experiment showing the highest shoot dry mass treatment was $60 \mathrm{mM}$, under ventilation and gro-lux, and the treatment which accumulate root dry mass to a lesser extent were $0 \mathrm{mM}$ with ventilation and cold light and $15 \mathrm{mM}$ without ventilation and cold light. In average, treatments with higher sucrose content in the culture medium, that is, $60 \mathrm{mM}$, under gro-lux lamps, presented the highest chlorophyll $a, b$ and total contents, than those under cold lamp. Steps of carbohydrates metabolism could be associated with the total soluble sugars (sucrose and reducing sugars) levels, highlighting the steps where nutrient requirements were higher, showing the role of the plantlets sink.
\end{abstract}

Key words: acclimatization, Araceae, plantlets metabolism

\section{RESUMO}

Monitoramento do final da fase in vitro de plântulas de Anthurium andraeanum. 0 estímulo à autotrofia em plântulas in vitro pode ser alcançado através de mudanças no meio de cultura, ou pela troca de tampas herméticas por tampas que permitam a troca de gases entre a cultura e 0 ambiente. Além disso, 0 uso de lâmpadas com distintos espectros de irradição tem propiciado bons resultados. Este trabalho foi conduzido com o objetivo de avaliar a ação isolada ou em conjunto de fatores que podem induzir a autotrofia em plântulas de $A$. andraeanum vc. Eidibel in vitro. 3 concentrações de sacarose foram usadas: 0, 15 e $60 \mathrm{mM}$ e para cada concentração foram empregados frascos com ventilação $\left(0,038{\left.\mathrm{~L} . \mathrm{h}^{-1}\right)}^{-1}\right.$ ou sem ventilação. Os frascos foram mantidos sob lâmpada fluorescente fria ou gro-lux. 0 final dos experimentos mostrou que o maior acumulo de massa seca da parte aérea ocorreu a 60 mM, sob ventilação e gro-lux, e os tratamento que acumularam menor massa seca de raízes foram $0 \mathrm{mM}$ com ventilação e sob luz fria e $15 \mathrm{mM}$ sem ventilação e luz fria. Em média, os tratamentos com o maior teor de sacarose no meio, $60 \mathrm{mM}$, sob lâmpada gro-lux, apresentaram as maiores concentrações de clorofila $a, b$ e total, do que sob luz fria. Os níveis de açúcares solúveis totais (sacarose e açúcares redutores) mostraram passos do metabolismo de carboidratos nessas plantas, realçando os momentos em que a exigência por nutrientes foi maior, destacando-se o papel de dreno das plântulas.

Palavras-chave: aclimatização, Araceae, metabolismo de plântulas 


\section{INTRODUCTION}

Anthurium andreanum has been of great significance in the Brazilian flowers production either for the cut flowers market or for the pot plants one, and the development of cultivars suitable to the tropical conditions (Tombolato, 2004) has contributed to the increasing growing area as well as to the high quality of flowers.

The Anthurium market has shown interest in plants uniformity, high floral quality as well as high yield, and the method of production through tissue culture in vitro, has been an important tool for the consecution of those purposes.

It is known that plantlets grown in vitro show feeble systems of protection against water loss, and don't have yet developed photosynthetic machinery for $\mathrm{CO}_{2}$ assimilation. Therefore is essential to provide suitable conditions to plantlets development from the beginning to transplantation. According to literature (Grattapaglia and Machado, 1998) besides low irradiance around and appropriate mineral nutrition (N:P:K), plantlets in vitro need high relative humidity, between 70 and $80 \%$ and air temperature never below $15^{\circ} \mathrm{C}$.

The success of a in vitro culture depends mainly on the physiological and anatomical adjustments that plantlets undergo at the last stage in vitro and throughout the ex vitro one, and the dry mass accumulation will be a consequence of the interaction of the environmental conditions and carbohydrates metabolism.

In general, the control of the environment and the medium culture changes are part of a serie of estrategies performed throughout the pre-acclimatization of plantlets, being of great importance in its growth, development, and proper morphological changes promotion, in vitro (Kozai et al., 1987; Kozai et al., 1991). Estimulation of autotrophy could be achieved through changes in the culture medium, or by changing the traditional hermetic caps by one that could allow gas exchanges between the culture and the environment (Kozai, 1991). Besides that, the use of lamps with distinct light emission spectrum has propitiated successful results, but mostly restrict to few plant species.

This work was carried out aiming to evaluate the either the combined or the single action of some factors that can induce autotrophy on in vitro $A$. andraeanum cv. Eidibel plantlets.

\section{MATERIAL AND METHODS}

A. andraeanum, cv. Eidibel plantlets kept in Murashige and Skoog (1962) medium were selected, being subsequently submitted to the same medium but under half salt concentration, in $300 \mathrm{~mL}$ capacity flasks with $50 \mathrm{~mL}$ of culture medium, with 5 plantlets perflask, for forty five days. Three sucrose concentrations were used: 0, 15 and $60 \mathrm{mM}$ and for each one, to kinds of flasks according to the cap ventilation: under $\left(0.038{\mathrm{~L} . \mathrm{h}^{-1}}^{-1}\right)$ and without ventilation, $\mathrm{u} / \mathrm{v}$ and $\mathrm{w} / \mathrm{v}$, respectively. Flasks were kept under cold light fluorescent lamps or under gro-lux lamps.

The experimental design was a random one, with three sucrose concentrations, and the use or not of ventilation and 2 kinds of illumination, that is twelve treatments and 10 replicates. Analyses were performed at 0 , fifteen, thirty and forty five days of growing in vitro, and for each treatment all the 10 replicates were analyzed.

Plantlets dry weight was performed by submitting them to $70^{\circ} \mathrm{C}$ temperature, until constant weight. At the end of the experiment chlorophyll $a, b$ and total contents were evaluated, according to the Arnon (1949) method and the results were expressed in mass units. Total soluble sugars contents were determined according to Dubois et al. (1956), reducing sugars contents were determined according to Somogyi (1952), and sucrose contents, according to Händel (1968).

\section{RESULTS}

There was no significant difference in shoot dry weight among treatments at the 0 day experiment (Table 1). From the onset of dry weight accumulation on, high values have been observed for the treatments $15 \mathrm{mM} \mathrm{u} / \mathrm{v}$ and cold lamps (CL) corresponding to $5.2 \mathrm{mg}$ and the treatment $60 \mathrm{mM}$, under the same conditions, corresponding to $5.3 \mathrm{mg}$. At the $30^{\text {th }}$ days the higher dry mass accumulation was for the treatments $0 \mathrm{mM} \mathrm{u} / \mathrm{v}$ and gro-lux (GL), corresponding to $5.3 \mathrm{mg} ; 15 \mathrm{mM} \mathrm{u} / \mathrm{v}$ and $\mathrm{CL}$, corresponding to $5.5 \mathrm{mg}$, and $60 \mathrm{mM} \mathrm{u} / \mathrm{v}$ and $\mathrm{CL}, 5.6 \mathrm{mg}$. At the end of the experiment showing the highest shoot dry mass treatment was $60 \mathrm{mM} \mathrm{u} / \mathrm{v}$ and $\mathrm{GL}$, corresponding to $7.2 \mathrm{mg}$.

Treatments that accumulated shoot dry mass to a lesser extent were: at the $15^{\text {th }}$ day, $0 \mathrm{mM}$ w/v and $\mathrm{CL}$, and $60 \mathrm{mM}$ $\mathrm{w} / \mathrm{v}$ and $\mathrm{GL}$; at the $30^{\text {th }}$ day treatments $0 \mathrm{mM} \mathrm{w} / \mathrm{v}$ and $\mathrm{CL}, 15$ $\mathrm{mM} \mathrm{w} / \mathrm{v}$ and $\mathrm{GL}$, and $60 \mathrm{mM} \mathrm{w} / \mathrm{v}$ and $\mathrm{GL}$; at $45^{\text {th }}$ day the 0 $\mathrm{mM} \mathrm{w} / \mathrm{v}$ and $\mathrm{CL}$.

Regarding to the root dry weight accumulation (Table 2), at the $30^{\text {th }}$ day better performance was observed on treatments $0 \mathrm{mM}$, under and without ventilation and GL, corresponding to 
$1.4 \mathrm{mg}, 15 \mathrm{mM}$ u/v and $\mathrm{CL}$, corresponding to $1.6 \mathrm{mg}, 15 \mathrm{mM}$ $\mathrm{u} / \mathrm{v}$ and $\mathrm{GL}$, corresponding to $1.4 \mathrm{mg}$ and $60 \mathrm{mM} \mathrm{u} / \mathrm{v}$ and $\mathrm{GL}$, corresponding to $1.5 \mathrm{mg}$. At the end of the experiment the treatment which accumulated root dry mass to a lesser extent were $0 \mathrm{mM} \mathrm{u} / \mathrm{v}$ and $\mathrm{CL}$, and $15 \mathrm{mM} \mathrm{w} / \mathrm{v}$ and $\mathrm{CL}$, both presenting $1.5 \mathrm{mg}$ root dry weight.

Tables 1 and 2 show that treatment with the highest sucrose content, under flasks ventilation and GL lamps happened to be the one that accumulated both shoot and root dry weight, that is plantlets under these conditions would be able to survive under the ex vitro environment.

Table 1. Average shoot dry mass accumulation (mg) in Anthurium andraeanum $\mathrm{cv}$. Eidibel plantlets at the $0,15^{\text {th }}, 30^{\text {th }}$ and $45^{\text {th }}$ days of acclimatization in vitro, in media culture with 0,15 and $60 \mathrm{mM}$ sucrose, under $(\mathrm{u} / \mathrm{v})$ or without $(\mathrm{w} / \mathrm{v})$ flasks ventilation and under cold lamps (CL) or gro-lux (GL).

\begin{tabular}{ccccc}
\hline \multirow{2}{*}{ Treatment } & \multicolumn{4}{c}{ Shoot dry mass } \\
\cline { 2 - 5 } & $\mathbf{0}$ days & $\mathbf{1 5}$ days & $\mathbf{3 0}$ days & $\mathbf{4 5}$ days \\
\hline $0 \mathrm{mM} \mathrm{w} / \mathrm{v} \mathrm{CL}$ & $3.16 \mathrm{~ns}^{1,2}$ & $3.44 \mathrm{~h}$ & $4.08 \mathrm{f}$ & $4.6 \mathrm{~g}$ \\
$0 \mathrm{mM} \mathrm{u} / \mathrm{v} \mathrm{CL}$ & $3.16 \mathrm{~ns}$ & $4.06 \mathrm{f}$ & $4.44 \mathrm{e}$ & $4.98 \mathrm{f}$ \\
$0 \mathrm{mM} \mathrm{w} / \mathrm{v} \mathrm{GL}$ & $3.16 \mathrm{~ns}$ & $4.7 \mathrm{cde}$ & $5.16 \mathrm{c}$ & $5.51 \mathrm{de}$ \\
$0 \mathrm{mM} \mathrm{u} / \mathrm{v} \mathrm{GL}$ & $3.16 \mathrm{~ns}$ & $5 \mathrm{bc}$ & $5.3 \mathrm{abc}$ & $5.72 \mathrm{~cd}$ \\
$15 \mathrm{mM} \mathrm{w} / \mathrm{v} \mathrm{CL}$ & $3.16 \mathrm{~ns}$ & $4.4 \mathrm{e}$ & $4.78 \mathrm{~d}$ & $5.3 \mathrm{e}$ \\
$15 \mathrm{mM} \mathrm{u} / \mathrm{v} \mathrm{CL}$ & $3.16 \mathrm{~ns}$ & $5.16 \mathrm{ab}$ & $5.54 \mathrm{ab}$ & $5.96 \mathrm{c}$ \\
$15 \mathrm{mM} \mathrm{w/v} \mathrm{GL}$ & $3.16 \mathrm{~ns}$ & $3.96 \mathrm{fg}$ & $4.18 \mathrm{ef}$ & $5.76 \mathrm{c}$ \\
$15 \mathrm{mM} \mathrm{u/v} \mathrm{GL}$ & $3.16 \mathrm{~ns}$ & $4.04 \mathrm{fg}$ & $4.4 \mathrm{e}$ & $5.94 \mathrm{c}$ \\
$60 \mathrm{mM} \mathrm{w/v} \mathrm{CL}$ & $3.16 \mathrm{~ns}$ & $4.54 \mathrm{de}$ & $4.84 \mathrm{~d}$ & $5.36 \mathrm{e}$ \\
$60 \mathrm{mM} \mathrm{u} / \mathrm{v} \mathrm{CL}$ & $3.16 \mathrm{~ns}$ & $5.34 \mathrm{a}$ & $5.58 \mathrm{a}$ & $6.94 \mathrm{~b}$ \\
$60 \mathrm{mM} \mathrm{w/v} \mathrm{GL}$ & $3.16 \mathrm{~ns}$ & $3.72 \mathrm{gh}$ & $4.08 \mathrm{f}$ & $5.82 \mathrm{c}$ \\
$60 \mathrm{mM} \mathrm{u} / \mathrm{v} \mathrm{GL}$ & $3.16 \mathrm{~ns}$ & $4.8 \mathrm{~cd}$ & $5.26 \mathrm{bc}$ & $7.22 \mathrm{a}$ \\
\hline
\end{tabular}

${ }^{1}$ According to Tukey test at $5 \%$.

${ }^{2}$ Values followed by same letters on columns do not differ significantly.

Table 2. Average root dry mass accumulation ( $\mathrm{mg}$ ) in Anthurium andraeanum cv. Eidibel plantlets at the $0,15^{\text {th }}, 30^{\text {th }}$ and $45^{\text {th }}$ days of acclimatization in vitro, in media culture with 0,15 and $60 \mathrm{mM}$ sucrose, under $(\mathrm{u} / \mathrm{v})$ or without $(\mathrm{w} / \mathrm{v})$ flasks ventilation and under cold lamps (CL) or gro-lux (GL).

\begin{tabular}{ccccc}
\hline \multirow{2}{*}{ Treatment } & \multicolumn{4}{c}{ Root dry mass } \\
\cline { 2 - 5 } & $\mathbf{0}$ days & $\mathbf{1 5}$ days & $\mathbf{3 0}$ days & $\mathbf{4 5}$ days \\
\hline $0 \mathrm{mM} \mathrm{w} / \mathrm{v} \mathrm{CL}$ & $0.9 \mathrm{~ns} \mathbf{1}^{1,2}$ & $1.04 \mathrm{~ns}$ & $1.22 \mathrm{c}$ & $1.56 \mathrm{~g}$ \\
$\mathrm{OmM} \mathrm{u} / \mathrm{v} \mathrm{CL}$ & $0.9 \mathrm{~ns}$ & $1.2 \mathrm{~ns}$ & $1.38 \mathrm{bc}$ & $1.52 \mathrm{~g}$ \\
$0 \mathrm{mM} \mathrm{w} / \mathrm{v} \mathrm{GL}$ & $0.9 \mathrm{~ns}$ & $1.08 \mathrm{~ns}$ & $1.4 \mathrm{abc}$ & $1.86 \mathrm{ef}$ \\
$0 \mathrm{mM} \mathrm{u} / \mathrm{v} \mathrm{GL}$ & $0.9 \mathrm{~ns}$ & $1.16 \mathrm{~ns}$ & $1.4 \mathrm{abc}$ & $1.74 \mathrm{fg}$ \\
$15 \mathrm{mM} \mathrm{w} / \mathrm{v} \mathrm{CL}$ & $0.9 \mathrm{~ns}$ & $1.3 \mathrm{~ns}$ & $1.46 \mathrm{ab}$ & $1.52 \mathrm{~g}$ \\
$15 \mathrm{mM} \mathrm{u} / \mathrm{v} \mathrm{CL}$ & $0.9 \mathrm{~ns}$ & $1.34 \mathrm{~ns}$ & $1.62 \mathrm{a}$ & $1.74 \mathrm{fg}$ \\
$15 \mathrm{mM} \mathrm{w} / \mathrm{v} \mathrm{GL}$ & $0.9 \mathrm{~ns}$ & $1.12 \mathrm{~ns}$ & $1.32 \mathrm{bc}$ & $2.06 \mathrm{de}$ \\
$15 \mathrm{mM} \mathrm{u} / \mathrm{v} \mathrm{GL}$ & $0.9 \mathrm{~ns}$ & $1.14 \mathrm{~ns}$ & $1.42 \mathrm{abc}$ & $2.34 \mathrm{c}$ \\
$60 \mathrm{mM} \mathrm{w} / \mathrm{v} \mathrm{CL}$ & $0.9 \mathrm{~ns}$ & $1.12 \mathrm{~ns}$ & $1.3 \mathrm{bc}$ & $1.82 \mathrm{f}$ \\
$60 \mathrm{mM} \mathrm{u} / \mathrm{v} \mathrm{CL}$ & $0.9 \mathrm{~ns}$ & $1.28 \mathrm{~ns}$ & $1.36 \mathrm{bc}$ & $2.98 \mathrm{~b}$ \\
$60 \mathrm{mM} \mathrm{w} / \mathrm{v} \mathrm{GL}$ & $0.9 \mathrm{~ns}$ & $1.12 \mathrm{~ns}$ & $1.24 \mathrm{bc}$ & $2.2 \mathrm{~cd}$ \\
$60 \mathrm{mM} \mathrm{u} / \mathrm{v} \mathrm{GL}$ & $0.9 \mathrm{~ns}$ & $1.28 \mathrm{~ns}$ & $1.46 \mathrm{ab}$ & $3.36 \mathrm{a}$ \\
\hline
\end{tabular}

${ }^{1}$ According to Tukey test at $5 \%$.

2 Values followed by same letters on columns do not differ significantly.
Table 3 shows the plantlets leaf area increase throughout the 45 days acclimatization. Significant differences among treatments could be seen after 15 days, and it is worth mentioning treatments $15 \mathrm{mM} \mathrm{u} / \mathrm{v}$ and $\mathrm{CL}, 15 \mathrm{mM} \mathrm{w} / \mathrm{v}$ and $\mathrm{GL}, 60 \mathrm{mM}$ u/v and GL, and $60 \mathrm{mM} \mathrm{w} / \mathrm{v}$ and GL, presenting significant larger leaf area until the end of the experiment. It is worth noting that treatments with $15 \mathrm{mM}$ sucrose presented larger leaf areas independently if plantlets were under $\mathrm{CL}$ or $\mathrm{GL}$ or $\mathrm{u} / \mathrm{v}$ or $\mathrm{w} / \mathrm{v}$, and $60 \mathrm{mM} \mathrm{u} / \mathrm{v}$ or $\mathrm{w} / \mathrm{v}$ and $\mathrm{GL}$. Treatments $15 \mathrm{mM} \mathrm{w} / \mathrm{v}$ and GL, $60 \mathrm{mM} \mathrm{u} / \mathrm{v}$ and GL, $60 \mathrm{mM} \mathrm{w} / \mathrm{v}$ and $\mathrm{GL}$, and $15 \mathrm{mM} \mathrm{u} / \mathrm{v} \mathrm{CL}$, showed leaf areas about 43.1, 41.9, 38.9 and $35.0 \%$, respectively as high as the other ones.

In average, $60 \mathrm{mM}$ sucrose treatments presented higher chlorophyll $a, b$ and total content (Table 4), while plantlets grown in $15 \mathrm{mM}$ sucrose showed intermediate values and those under in $0 \mathrm{mM}$ sucrose had the lowest chlorophylls content. Chlorophyll a content was higher then chlorophyll $b$ (Table 4), in every treatment, corresponging to 2.22 on treatments under $0 \mathrm{mM}, 2.89$ under $15 \mathrm{mM}$ and 2.45 under $60 \mathrm{mM}$. Total chlorophyll averages were 1.44 and 1.17 higher under 60 and $15 \mathrm{mM}$ sucrose, respectively, when compared with the content observed under $0 \mathrm{mM}$. The ratio chlorophyll a:chlorophyll $b$ varied significant among treatments, with average values of 2.2 for the $0 \mathrm{mM}, 2.3$ for $15 \mathrm{mM}$ and 2.45 for the $60 \mathrm{mM}$ sucrose.

Table 3. Average leaf area $\left(\mathrm{cm}^{2}\right)$ in Anthurium andraeanum cv. Eidibel, plantlets at the $0,15^{\text {th }}, 30^{\text {th }}$ and $45^{\text {th }}$ days of acclimatization in vitro, in media culture with 0,15 and $60 \mathrm{mM}$ sucrose, under $(\mathrm{u} / \mathrm{v})$ or without $(\mathrm{w} / \mathrm{v})$ flasks ventilation and under cold lamps (CL) or gro-lux (GL).

\begin{tabular}{ccccc}
\hline \multirow{2}{*}{ Treatment } & \multicolumn{4}{c}{ Leaf area } \\
\cline { 2 - 5 } & $\mathbf{0}$ days & $\mathbf{1 5}$ days & $\mathbf{3 0}$ days & $\mathbf{4 5}$ days \\
\hline $0 \mathrm{mM} \mathrm{w} / \mathrm{v} \mathrm{CL}$ & $0.94 \mathrm{~ns}$ & $1.62 \mathrm{~d}$ & $2.45 \mathrm{e}$ & $2.94 \mathrm{c}$ \\
$0 \mathrm{mM} \mathrm{u} / \mathrm{v} \mathrm{CL}$ & $0.94 \mathrm{~ns}$ & $2.15 \mathrm{~cd}$ & $2.71 \mathrm{de}$ & $2.97 \mathrm{c}$ \\
$0 \mathrm{mM} \mathrm{w} / \mathrm{v} \mathrm{GL}$ & $0.94 \mathrm{~ns}$ & $2.29 \mathrm{~cd}$ & $2.92 \mathrm{~d}$ & $3.29 \mathrm{bc}$ \\
$0 \mathrm{mM} \mathrm{u} / \mathrm{v} \mathrm{GL}$ & $0.94 \mathrm{~ns}$ & $2.29 \mathrm{~cd}$ & $2.91 \mathrm{~d}$ & $3.29 \mathrm{bc}$ \\
$15 \mathrm{mM} \mathrm{w} / \mathrm{v} \mathrm{CL}$ & $0.94 \mathrm{~ns}$ & $3.16 \mathrm{ab}$ & $3.46 \mathrm{bc}$ & $3.78 \mathrm{~b}$ \\
$15 \mathrm{mM} \mathrm{u} / \mathrm{v} \mathrm{CL}$ & $0.94 \mathrm{~ns}$ & $3.58 \mathrm{a}$ & $4.15 \mathrm{a}$ & $4.51 \mathrm{a}$ \\
$15 \mathrm{mM} \mathrm{w} / \mathrm{v} \mathrm{GL}$ & $0.94 \mathrm{~ns}$ & $3.17 \mathrm{ab}$ & $3.82 \mathrm{ab}$ & $4.78 \mathrm{a}$ \\
$15 \mathrm{mM} \mathrm{u} / \mathrm{v} \mathrm{GL}$ & $0.94 \mathrm{~ns}$ & $2.48 \mathrm{bc}$ & $2.82 \mathrm{de}$ & $3.31 \mathrm{bc}$ \\
$60 \mathrm{mM} \mathrm{w} / \mathrm{v} \mathrm{CL}$ & $0.94 \mathrm{~ns}$ & $2.37 \mathrm{~cd}$ & $2.85 \mathrm{de}$ & $3.27 \mathrm{bc}$ \\
$60 \mathrm{mM} \mathrm{u} / \mathrm{v} \mathrm{CL}$ & $0.94 \mathrm{~ns}$ & $2.49 \mathrm{bc}$ & $3.12 \mathrm{~cd}$ & $3.86 \mathrm{~b}$ \\
$60 \mathrm{mM} \mathrm{w} / \mathrm{v} \mathrm{GL}$ & $0.94 \mathrm{~ns}$ & $3.77 \mathrm{a}$ & $3.95 \mathrm{a}$ & $4.64 \mathrm{a}$ \\
$60 \mathrm{mM} \mathrm{u} / \mathrm{v} \mathrm{GL}$ & $0.94 \mathrm{~ns}$ & $3.49 \mathrm{a}$ & $3.87 \mathrm{ab}$ & $4.74 \mathrm{a}$ \\
\hline
\end{tabular}

${ }^{1}$ According to Tukey test at $5 \% .2$ Values followed by same letters on columns do not differ significantly. 
Table 4. Chlorophyll content ( $\mu \mathrm{g} .100 \mathrm{mg}^{-1}$ fresh mass), after 45 days of acclimatization in vitro, in media culture with 0,15 and $60 \mathrm{mM}$ sucrose, under $(\mathrm{u} / \mathrm{v})$ or without $(\mathrm{w} / \mathrm{v})$ flasks ventilation and under cold lamps $(\mathrm{CL})$ or gro-lux (GL).

\begin{tabular}{ccccc}
\hline \multirow{2}{*}{ Treatment } & \multicolumn{3}{c}{ Chlorophyll content } & \multirow{2}{*}{ Chl a/b ratio } \\
\cline { 2 - 4 } & Chl $\boldsymbol{a}$ & Chl $\boldsymbol{b}$ & Total Chl & \\
\hline $0 \mathrm{mM} \mathrm{w} / \mathrm{v} \mathrm{CL}$ & $2.91 \mathrm{e}$ & $1.48 \mathrm{de}$ & $4.39 \mathrm{e}$ & $1.98 \mathrm{c}$ \\
$0 \mathrm{mM} \mathrm{u} / \mathrm{v} \mathrm{CL}$ & $3.19 \mathrm{e}$ & $1.46 \mathrm{e}$ & $4.66 \mathrm{e}$ & $2.18 \mathrm{bc}$ \\
$0 \mathrm{mM} \mathrm{w} / \mathrm{v} \mathrm{GL}$ & $5.33 \mathrm{bcd}$ & $2.19 \mathrm{abc}$ & $7.51 \mathrm{bcd}$ & $2.43 \mathrm{ab}$ \\
$0 \mathrm{mM} \mathrm{u} / \mathrm{v} \mathrm{GL}$ & $4.48 \mathrm{~cd}$ & $2.02 \mathrm{bcd}$ & $6.5 \mathrm{~cd}$ & $2.22 \mathrm{bc}$ \\
$15 \mathrm{mM} \mathrm{w/v} \mathrm{CL}$ & $5.1 \mathrm{bcd}$ & $2.15 \mathrm{abc}$ & $7.25 \mathrm{bcd}$ & $2.37 \mathrm{ab}$ \\
$15 \mathrm{mM} \mathrm{u} / \mathrm{v} \mathrm{CL}$ & $4.09 \mathrm{de}$ & $1.83 \mathrm{cde}$ & $5.92 \mathrm{de}$ & $2.23 \mathrm{abc}$ \\
$15 \mathrm{mM} \mathrm{w/v} \mathrm{GL}$ & $5.41 \mathrm{bc}$ & $2.24 \mathrm{abc}$ & $7.65 \mathrm{abcd}$ & $2.42 \mathrm{ab}$ \\
$15 \mathrm{mM} \mathrm{u} / \mathrm{v} \mathrm{GL}$ & $4.15 \mathrm{de}$ & $1.84 \mathrm{cde}$ & $6.09 \mathrm{de}$ & $2.26 \mathrm{abc}$ \\
$60 \mathrm{mM} \mathrm{w/v} \mathrm{CL}$ & $5.59 \mathrm{abc}$ & $2.31 \mathrm{abc}$ & $7.9 \mathrm{abc}$ & $2.42 \mathrm{ab}$ \\
$60 \mathrm{mM} \mathrm{u} / \mathrm{v} \mathrm{CL}$ & $6.67 \mathrm{a}$ & $2.64 \mathrm{a}$ & $9.31 \mathrm{a}$ & $2.53 \mathrm{a}$ \\
$60 \mathrm{mM} \mathrm{W} / \mathrm{v} \mathrm{GL}$ & $4.98 \mathrm{~cd}$ & $2.1 \mathrm{abc}$ & $7.08 \mathrm{~cd}$ & $2.36 \mathrm{ab}$ \\
$60 \mathrm{mM} \mathrm{u} / \mathrm{v} \mathrm{GL}$ & $6.32 \mathrm{ab}$ & $2.55 \mathrm{ab}$ & $8.87 \mathrm{ab}$ & $2.48 \mathrm{ab}$ \\
\hline
\end{tabular}

${ }^{1}$ According to Tukey test at $5 \%$.

${ }^{2}$ Values followed by same letters on columns do not differ significantly.
Figures $1 \mathrm{~A}, 1 \mathrm{~B}, 1 \mathrm{C}$ e $1 \mathrm{D}$ show that there were no significant differences among the $0 \mathrm{mM}$ sucrose treatment, independently of flasks being ventilated or not and of the type of illumination. At the 0 day it was observed that plantlets presented low sucrose content while the reducing sugars content was high. At the $15^{\text {th }}$ day total sugars and reducing sugars content decreased, while sucrose content shows an increase. At the $30^{\text {th }}$ day the lowest contents of sucrose, reducing sugars and total sugars were observed. Henceforward and then until the end of the experiment at the $45^{\text {th }}$ day, sucrose content has kept the same or showed a decrease while reducing sugars content showed a sharp increase.
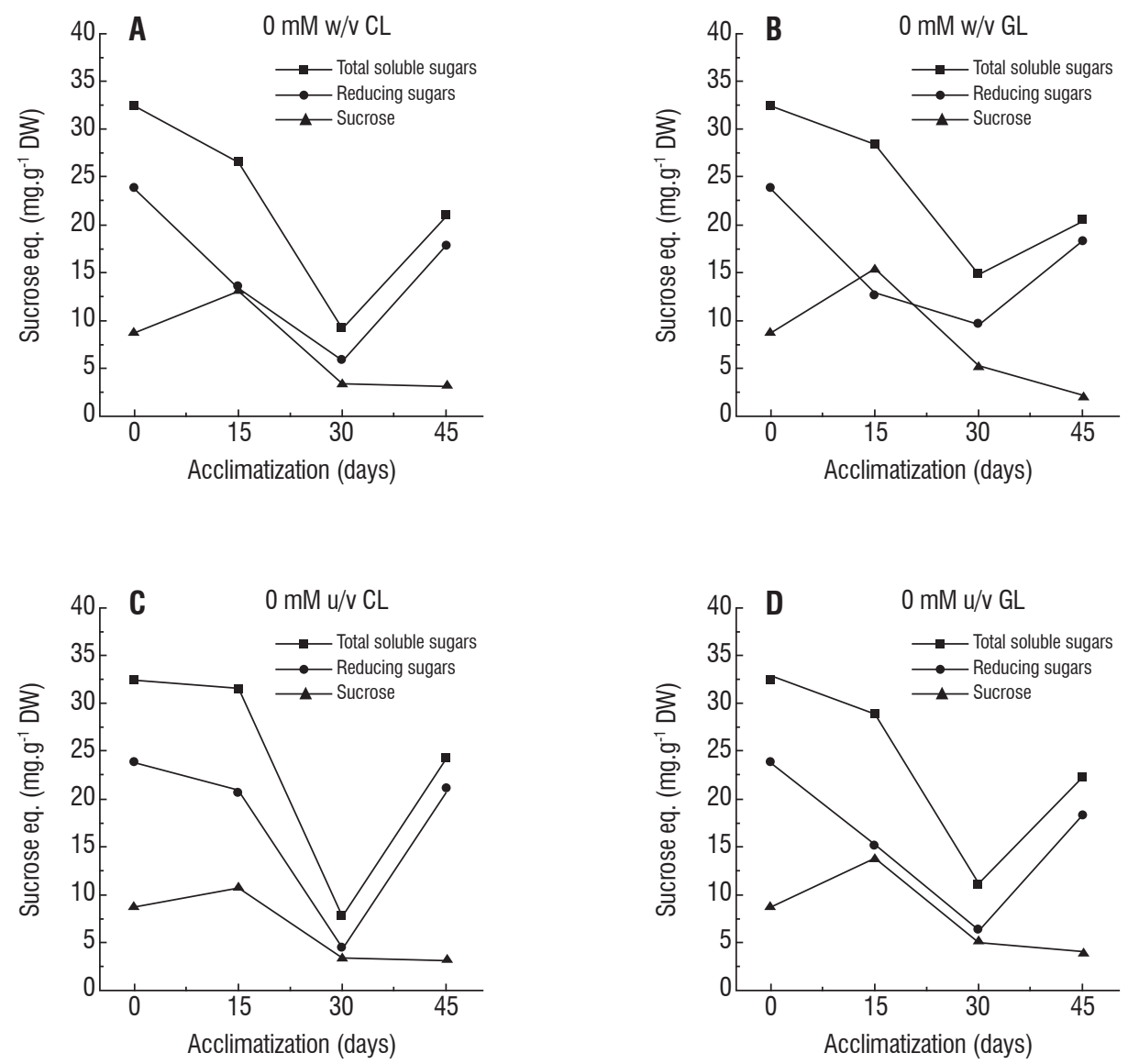

Figure 1. Total soluble sugars, reducing sugars and sucrose content variation, in Anthurium andraeanum cv. Eidibel plantlets, throughout 45 days of acclimatization in vitro, in media culture with $0 \mathrm{mM}$ sucrose, under (u/v) or without (w/v) flasks ventilation and under cold lamps (CL) or gro-lux (GL). 
The results showed in Figures $2 \mathrm{~A}, 2 \mathrm{~B}, 2 \mathrm{C}$ and $2 \mathrm{D}$, under $15 \mathrm{mM}$ sucrose, show that the total soluble sugars, reducing sugars and sucrose content varied significantly throughout the experiment. In general the variations on carbohydrates content seemed to have been similar in all treatments. Under $\mathrm{w} / \mathrm{v}$ and $\mathrm{CL}$ and $\mathrm{u} / \mathrm{v}$ and $\mathrm{GL}$, the total soluble sugars level showed an increase from the 0 to the $15^{\text {th }}$ day in vitro (Figures $2 \mathrm{~A}$ and $2 \mathrm{C}$ ). At the same period, all treatments showed decreases in the reducing sugars, while sucrose content has increased. From the 15 to the $30^{\text {th }}$ day, a decrease in reducing sugars as well as in sucrose was
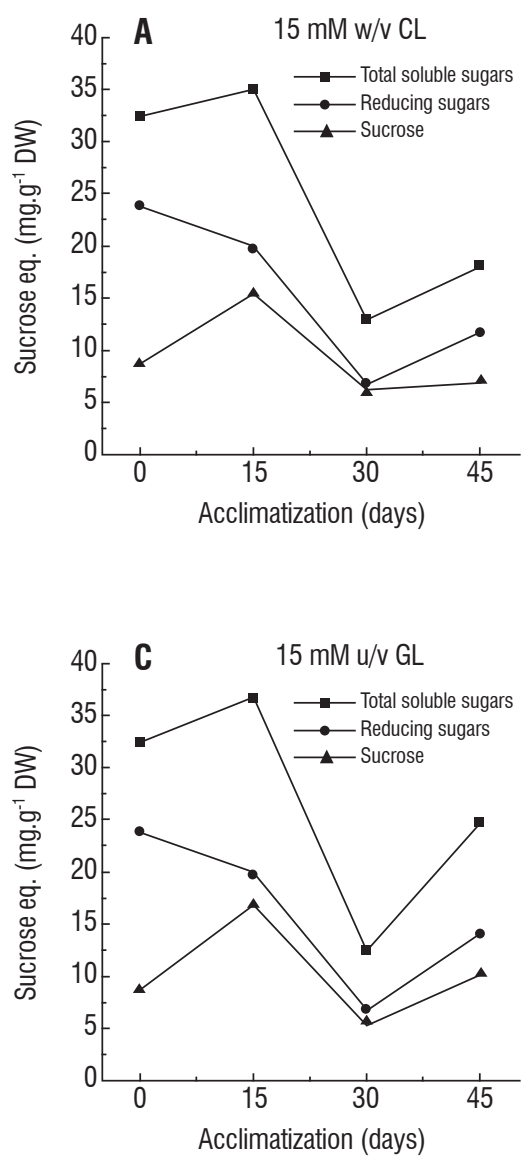

observed, coupled with a decrease in total soluble sugars content. The lowest level of all the carbohydrates were observed at the $30^{\text {th }}$ experiment. Figures $2 \mathrm{~A}$ and $2 \mathrm{C}$, showed that from the 30 to the $45^{\text {th }}$ day an increase in reducing sugars as well as in sucrose content was observed. At the same period, Figures $2 \mathrm{~B}$ and $2 \mathrm{D}$, show an increase in reducing sugars level and a decrease in sucrose content, coupled with an increase in total soluble sugars much lower however, than that one observed at the 0 day experiment. It is worth noticing that from the 15 to the $30^{\text {th }}$ the reducing sugars and sucrose levels were similar.
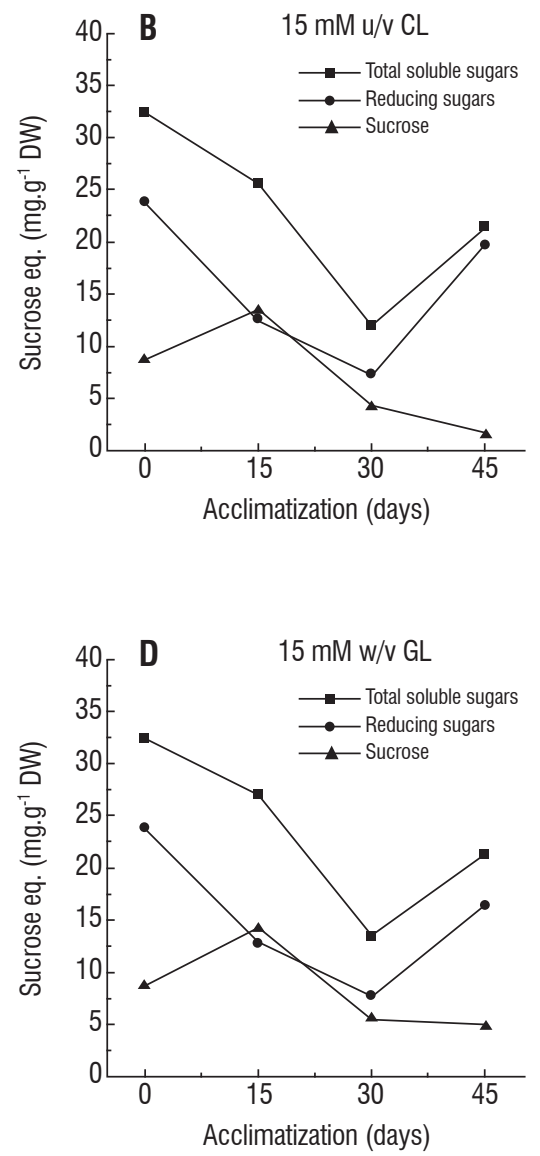

Figure 2. Total soluble sugars, reducing sugars and sucrose content variation, in Anthurium andraeanum cv. Eidibel plantlets, throughout 45 days of acclimatization in vitro, in media culture with $15 \mathrm{mM}$ sucrose, under (u/v) or without (w/v) flasks ventilation and under cold lamps (CL) or gro-lux (GL).

Figures $3 \mathrm{~A}, 3 \mathrm{~B}, 3 \mathrm{C}$ and $3 \mathrm{D}$ show the variations in total soluble sugars, reducing sugars and sucrose contents under $60 \mathrm{mM}$ sucrose. Figures $3 \mathrm{~A}, 3 \mathrm{~B}$ and $3 \mathrm{C}$, showed that the variations in carbohydrates contents were similar, and that there was no sharp decrease of them after 30 days in vitro, as it was observed under 0 and $15 \mathrm{mM}$. From the 0 to the 15 day, there was a decrease in reducing sugars and in sucrose levels, which were maintained steady from the 15 to the 30 ${ }^{\text {th }}$ day. Henceforward until the $45^{\text {th }}$ day, the sucrose levels increased while those of reducing sugars either unchanged 
or showed a slight decrease. Meanwhile, total soluble sugars contents showed an increase, mainly due to the increase in sucrose levels.

Figure 3D shows an atypical performance when compared either with those of Figures 3A, 3B and 3C, or those under the other sucrose concentration in the culture medium
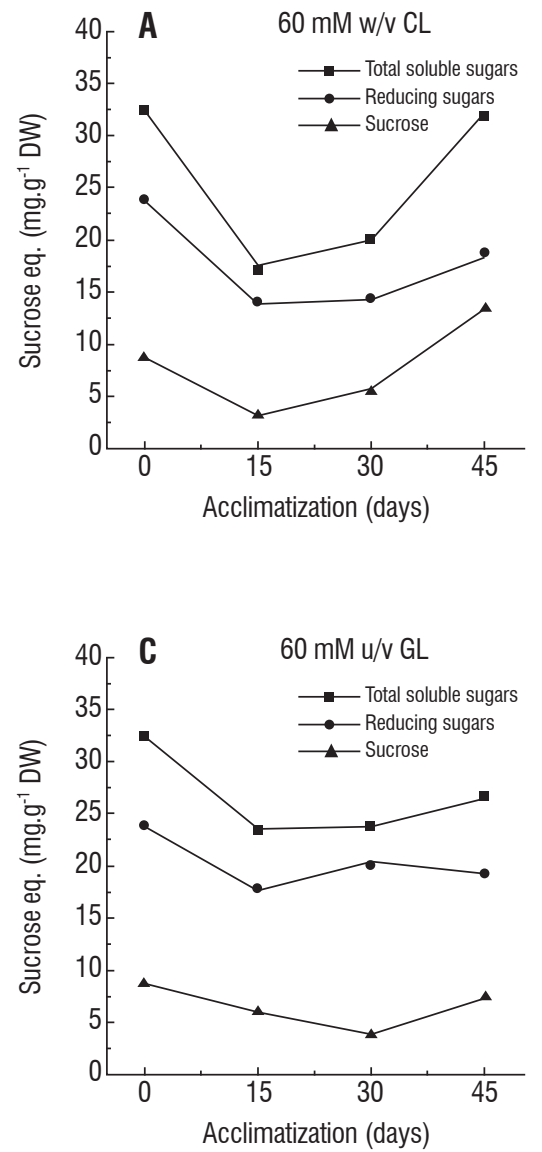

(Figures 1 and 2). From the 0 to the $15^{\text {th }}$ day, the reducing sugars and sucrose contents decreased coupled with the decrease in total soluble sugars content. Henceforth until the end of the experiment at the $45^{\text {th }}$ day, the reducing sugars as well as the sucrose levels showed a significant increase, coupled with an increase in total soluble sugars levels.
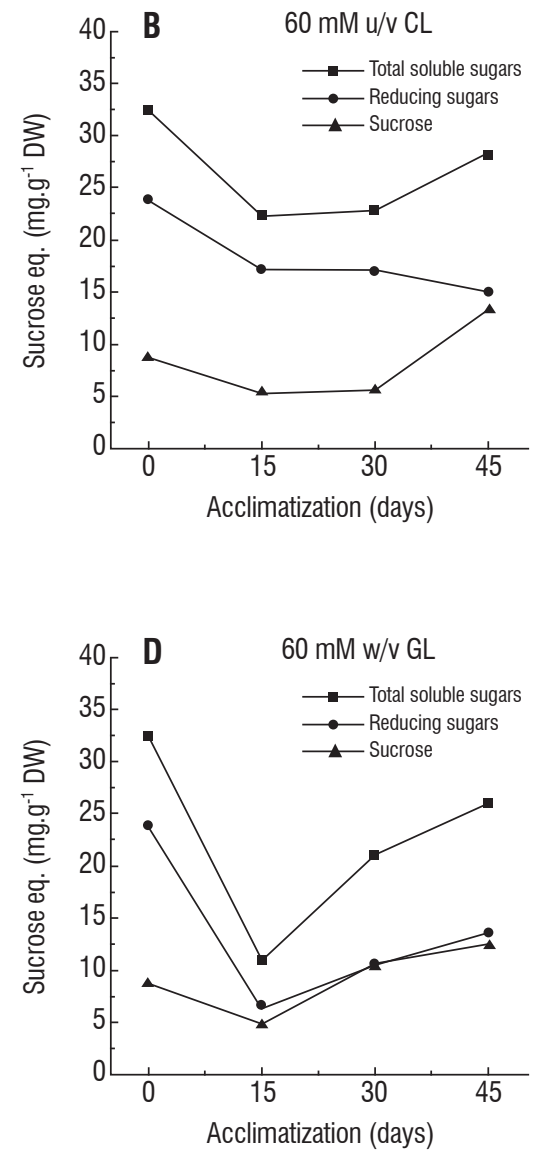

Figure 3. Total soluble sugars, reducing sugars and sucrose content variation, in Anthurium andraeanum cv. Eidibel plantlets, throughout 45 days of acclimatization in vitro, in media culture with $60 \mathrm{mM}$ sucrose, under (u/v) or without (w/v) flasks ventilation and under cold lamps (CL) or gro-lux (GL).

\section{DISCUSSION}

The high total soluble sugars levels, mainly reducing sugars at the beginning of the experiment and the subsequent metabolic changes throughout the 45 days may indicate that previously to the treatments imposition, plantlets had absorbed sucrose from the culture media which enzimatically was broken down to glucose and fructose. Taking into account that the sucrose levels have kept low, the results indicate high catalytic enzymes activity but low sucrose demand, that is the reducing sugars were not consumed highly mainly at the $15^{\text {th }}$ day. On the $30^{\text {th }}$ day there was a decrease in the total soluble 
sugars, reducing sugars and sucrose level, probably due to a highest demand for photoassimilates at this period, probably due to the maximum sink strength at that moment.

According to Hazarika (2006), growth and respiration in vitro, require a steady sucrose exogenous supply as a carbon source. However, high sucrose and salts concentration within the culture medium seem to restrain photosynthetic efficiency. Also, Kovtum and Daie (1995) observed that a exogenous sucrose source speeds leaves growth and development and its transition sink-source in Beta vulgaris L. plantlets grown in vitro, and concluded that the question was not the source but the sink limitation, until the plantlets themselves developed its capacity of metabolizing carbohydrates. Ticha et al. (1998) have considered that exogenous sucrose would prevent photoinhibition to happen.

The increasing sucrose concentration within the culture medium maximizes the role of the nutrients in persistent leaves (Grout and Millam, 1985; Desjardins et al., 1987), and it is known that high sucrose concentration has propitiate increasing shoot dry weight. Hazarika et al. (2000) observed that pre-conditionement of Citrus sp in vitro under $3 \%$ sucrose has increased subsequent survival and growth ex vitro. According to the same authors, a linear increase in the biochemical components with sucrose addition to the culture medium.

From the $45^{\text {th }}$ day on, there was a sink strength decrease that could be corroborated by the high reducing sugars content, while sucrose content was kept at its previous levels. The results indicate an increase in the sucrose metabolism enzymes which could be due to a decrease of sinks strength or to an imbalance in carbohydrates partitioning (Stancato et al., 2001). Once plantlets from $60 \mathrm{mM}$ treatment presented higher dry weight (Tables 1, 2, and 3 ) it is possible that a higher demand for reducing sugars has resulted in a higher demand for sucrose.

When the gain of dry mass was related to the leaf area, it seemed that plantlets under 15 and $60 \mathrm{mM}$ sucrose in the culture medium are among those which presented a bigger leaf area, indicating a higher demand for sugars from the culture medium to be allocated to the leaves, resulting a increase in leaf area. By the way, the leaf area does not seem to be a suitable variable for to be used to evaluate the plantlets acclimatization, although Premkumar et al. (2001) have pointed out that the success of acclimatization depends on the sources inside the developing plantlets. According to Ticha et al. (1998), the addition of sucrose to the culture medium influenced positively the increase of biomass and leaf area as well as accumulation of chlorophyll and photosynthetic capacity in tobacco plantlets.

Chlorophyll contents are in agreement with those observed in plantlets of other species in vitro (Carvalho et al., 2005). The results show that chlorophyll levels are better related with sucrose concentration in the culture médium than the lamp type. GL lamps have the emission spectrum in the range of blue and red and the CL lamps emit in blue, but the emission spectrum did not interfere on chlorophyll levels, although its capacity of capturing and transforming light energy depends on the simultaneous absortion of blue and red wave lengths. Light intensity is the same for both lamps.

According to Premkumar (2001), while low light inhibits chloroplasts development, sugars content in the culture medium may restrain the photosynthetic enzymes activity, as for instance the Rubisco (EC 4.1.1.39). Watanabe et al. (1990); Tanaka et al. (1991); Rival et al. (1999), observed that Chrysantemum morifolium L., Spathiphyllum wallisi Regel and coconut plantlets grown in vitro with $3 \%$ sucrose, presented low Rubisco levels, what is characteristic for in vitro plantlets. According to Carvalho et al., (2005) low light intensity inhibit the proper development of chloroplasts, which exhibit low content and activity of Rubisco in vitro.

In average, plantlets grown under gro-lux lamps grew faster than those under cold light grown under the same sucrose concentration, that is $60 \mathrm{mM}$. This may imply that although the lamps emission spectrum has not been involved in the chlorophyll level, there could have been higher Rubisco activity associated to sucrose level in the culture medium, resulting in a better utilization of the light energy. Studies by Kozai et al. (1987) with species of ornamental plantlets showed that the $\mathrm{CO}_{2}$ level in the flasks, decreased from $3000-9000 \mathrm{ppm}$, in the dark period to $90 \mathrm{ppm}$ in the light period indicating that plantlets were able to photosynthesize throughout the light period.

Total soluble sugars (sucrose and reducing sugars) showed steps of the carbohydrates metabolism mainly the higher the demand for nutrients by plantlets sinks. Although the carbohydrates level in the culture medium 
may have contributed to plantlets heterotrophy, the fact that high sugars concentrations have decreased significantly the medium osmotic potential besides the possible gas exchanges propitiated by the flasks with the holed cap, allowed a degree of autotrophy expressed by the dry weight accumulation in plantlets. Even under low light conditions it is possible to speculate that plantlets grown in 15 and $60 \mathrm{mM}$ sucrose and holed caps have grown not only as a function of nutrients availability in the culture medium, but also via photosynthesis.

\section{CONCLUSIONS}

- The plantlets dry mass accumulation were positively correlated with the higher sucrose content in the culture medium;

- The ventilation in the flasks contributed significantly to the plantlets dry mass accumulation and to its acclimatization and consequently to its vigor;

- The emission spectrum of the GL lamps showed a positive influence on the plantlets development.

\section{REFERENCES}

Arnon DJ (1949) Copper enzymes in isolated chloroplasts polyphenoloxidase in Beta vulgaris. Plant Physiol. 24:1-15.

Carvalho LC, Esquivel MG, Martins I, Ricardo CP, Amâncio S (2005) Monitoring the stability of Rubisco in micropropagated grapevine (Vitis vinifera L.) by two-dimensional electrophoresis. J. Plant Physiol. 162:365-374.

Desjardins Y, Gosselin A, Yelle S (1987) Acclimatization of ex vitro strawberry plantlets in CO2-enriched enviroments and suplementary lighting. J. Amer. Soc. Hort. Sci. 112:846-851.

Dubois M, Gilles KA, Hamilton JK, Rebers PA, Smith F (1956) Colorimetric method for determination of sugars and related substances. Anal. Chem. 28:350-356.

Grattapaglia D, Machado MA (1998) Micropropagação. In: Torres AC, Caldas LS, Buso JA (eds) Cultura de tecidos e transformação genética de plantas. pp.183-260, Embrapa-SPI e Embrapa-CNPH, Brasília, Brasil.
Grout MC, Millan S (1985) Phothosynthetic development of micropropagated strawberry plantlets following transplanting. Ann. Bot. 55:129-131.

Hazarika BN, Parthasarathy VA, Nagaraju V (2000) Sucrose induced biochemical changes in in vitro microshoots of Citrus species. Indian J. Hort. 57:27-31.

Hazarika BN (2006) Morpho-physiological disorders in vitro culture of plants. Scientia Horticulturae 108:105-120.

Kozai T, Hayashi M, Hirosawa Y, Kodama T, Watanabe I (1987) Environmental control for acclimatization of in vitro. J. Agric. Met. 42:348-358.

Kozai T, Fujiwara K, Hayashi, M, Aitken-Christie J (1991) The in vitro environment and its control in micropropagation. In: Kurata $\mathrm{K}$ and Kozai T (eds) Transplant production systems. pp.247-282, Kluwer Academic Publishers, Dordrecht, The Netherlands.

Kovtum Y, and Daie J (1995) End product control of carbon metabolism in culture grown sugarbeet plant. Plant Physiol. 108:1647-1657.

Murashige T and Skoog F (1962) A revised medium for rapid growth and bioassays for tobacco cultures. Physiol. Plant. 15:473-497.

Premkumar A, Mercado JA, Quesada MA (2001) Effects of in vitro tissue culture conditions and acclimatization on the contents of Rubisco, leaf soluble proteins, photosynthetic pigments, and C/N ratio. J. Plant Physiol. 158:835840.

Rival AK, Triques, K, Beule T, Nato A, Lavergne D, Santamaria J, Verdeil JL, Hocher V, Oropeza C, Hamon S (1999) A multi-parameter approach for the study of in vitro photosynthesis. Curr. Plant Sci. Biotechnol. Agric. 36:437440.

Somogyi M (1952) Notes on sugar determination. J. Biol. Chem. 195:19-23. Stancato GC, Mazzafera P, Buckeridge, MS (2001) Effect of a drought period on the mobilization of non-structural carbohydrates, photosynthetic efficiency and water status in an epiphytic orchid. Plant Physiol. Biochem. 39:10091016.

Tanaka F, Watanabe Y, Shimada N (1991) Effect of oxygen concentrations on photorespiration in Chrysanthemum morifolium plantlets in vitro cultured photoautotrophically and photomixotrophically. Shokubutsu Soshiki Baiyo 8:87-93.

Ticha I, Cap F, Pacovska D, Hofman P, Heisel D, Capkova V, Schafer C (1998) Culture on sugar medium enhance photosynthetic capacity and high light resistence of plantlets grown in vitro. Physiol. Plant. 102 155-162.

Tombolato AFC (2004) Recursos genéticos e melhoramento do anturio (Anthurium andraeanum) no IAC-APTA. Revista Brasileira de Horticultura Ornamental 10:1-59.

Van Handel E (1968) Direct microdetermination of sucrose. Anal. Biochem. 22:280-283.

Watanabe K, Watanabe Y, Shimada N (1990) Effect of sucrose concentration in the medium on growth, apparent photosynthesis and ribulose-1,5bisphosphate carboxylase of Spathiphyllum wallisi plantlets in aeration culture. Shokubutsu Soshiki Baiyo 7:74-79. 